\title{
CHEMICAL, TECHNOLOGICAL AND SENSORY PROPERTIES OF MEAT FROM DIFFERENT CATTLE GENOTYPES
}

\author{
S. Aleksić, M. M. Petrović, V. Pantelić, Ž. Novaković, D. Ostojić- \\ Andrić, N. Stanišić, D. Nikšić
}

Institute for Animal Husbandry, 11080, Belgrade-Zemun, Republic of Serbia

Corresponding author: saleksic@mail.com

Original scientific paper

\begin{abstract}
Possibilities for improvement of the quality of beef in population of Domestic spotted cattle breed (D) by application of industrial crossing with French fattening breeds Charolais (DxS) and Limousine (DxL) were investigated. Comparative research included 25 heads of young cattle of DxS, 18 crosses of DxL and 21 crosses of D genotype. Results of the analysis of chemical composition of longissimus muscle in young cattle show significant statistical differences $(\mathrm{P}<0.05)$ in percentage of intramuscular fat, the highest value was determined in cattle of group DxS (2.37\%), and in total pigments which was the highest in cattle of group D (101.12 ppm). Young cattle in group D had the lowest value of the meat shear force after heat treatment $\left(5.43 \mathrm{~kg} / \mathrm{cm}^{2}\right)$, i.e. they had the tenderest meat. Data obtained in the sensory analysis of cooked meat were very high and showed no significant differences between groups. Statistically significant difference $(\mathrm{P}<0.05)$ was established only in assessment of aroma/taste, which was somewhat higher in young cattle of group DxS (4.87). Data obtained in this trial justify the economic goal of crossing of domestic Simmental breed with noble cattle breeds in production of meat of high quality, which is of great importance both for producers (farmers) and final customer (consumer).
\end{abstract}

Key words: cattle, genotype, meat quality

\section{Introduction}

With the aim of improvement of production and quality of meat, the trend of crossing of existing genotypes of cattle with fattening bulls is more and more present. Application of method of crossing enables in offspring ( $F_{1}$ generation) demonstration of heterosis effect in fattening and meat quality traits. Results of the crossing with fattening breeds (Čobić et al., 1990; Aleksić et al., 1997, 2005, 2006) indicate that considerable effects in production of calves, fattening of young cattle and quality of meat can be realized in this way.

In Serbia, production of beef is based on Domestic spotted breed, which is breed with combined production traits. Factors affecting the quality of meat can be 
divided into pre mortal (genetic basis, housing, preparation for slaughtering, etc.) and post mortal (slaughtering procedure and cooling of meat). Research indicates small differences in sensory traits of meat from different genotypes, and authors explanations are that they are mainly caused by the physiological age, since different breeds of the same age don't have the same slaughter maturity (Harrington, 1985; Buchter, 1985).

One of the ways to increase the production of beef is to obtain high quality calves for fattening by the method of industrial crossing of domestic Simmental breed with meat breeds. Regarding to this, the aim of this study was to estimate chemical, technological and sensory characteristics of beef meat from different genotypes.

\section{Materials and Methods}

Research was carried out on three groups of young cattle of different genotypes: DxS - Domestic spotted x Charolais, DxL - Domestic spotted x Limousine and D - Domestic spotted breed of Simmental type. Comparative research included 25 heads of young cattle of DxS, 18 crosses of DxL and 21 crosses of D genotype. Breeding of cattle, slaughtering and primary processing were carried out on experimental farm and slaughterhouse of the Institute for Animal Husbandry (Belgrade, Serbia). During the fattening period the rearing system was free, and food consisted of concentrated feeds, hay and corn grain silage.

After slaughtering, carcasses were chilled at $+4^{\circ} \mathrm{C}$ for 24 hours. Samples were taken of the loin section of the back muscle (longissimus dorsi), between $12^{\text {th }}$ and $13^{\text {th }}$ rib. Water binding capacity (WBC), according to method by Grau and Hamm (1953) and $\mathrm{pH}$ value of meat, measured using $\mathrm{pH}$-meter with glass electrode Hanna, HI 83141 (Hanna Instruments, USA), were determined in samples of longissimus dorsi 24 hours post mortem. In all samples, main chemical composition was determined: quantity of water by drying of samples at temperature of $105^{\circ} \mathrm{C}$ to a constant mass, quantity of intramuscular fat by method of extraction according to Soxlet (with petrol-ether as solvent), quantity of proteins using method according to Kjeldahl and quantity of mineral matters (ashes) by burning of samples at temperature of $550-600^{\circ} \mathrm{C}$ to a constant mass $(A O A C, 1990)$. Content of total pigments was determined using the method according to Horsney (Bunning and Hamm, 1970).

Cooking loss was determined in the following way: sample of size of $3 \times 4$ $\mathrm{x} 1,5 \mathrm{~cm}$ is weighed and put into glass with boiling water and cooked for 10 minutes; meat sample is then removed from the glass, filter paper is used to remove any excess water and sample is weighed, immediately. Difference in mass of sample before and after cooking represents loss of mass during heat treatment (cooking loss) and it is expressed in percentages.

Samples used for determination of cooking loss were also used for determination of meat shear force $\left(\mathrm{kg} / \mathrm{cm}^{2}\right)$. Muscles have been cut to parts of size 
of $1 \mathrm{x} 1 \mathrm{~cm}$ in the direction of muscle fibre extension. Meat tenderness, expressed by shear force, was measured on Warner-Bratzler apparatus. Higher values read out on the apparatus marked higher values of shear force, i.e. firmer meat.

Sensory analysis was done on samples of longissimus dorsi, of size of $2 \mathrm{x}$ $2 \times 2 \mathrm{~cm}$ subsequent to cooking with boiling water for 10 minutes. System of 5 points was used for scoring: 1-exceptionally unacceptable to 5-exceptionally acceptable. Following meat attributes were determined/scored: softness, succulence, taste and aroma. Five (5) semi-trained scorers participated in scoring.

Obtained data was analyzed statistically using ANOVA procedure of Statistica 7 software (StatSoft inc, USA). Statistically significant difference between mean values was determined using t-test. Statistical parameters calculated are: mean value $(\overline{\mathrm{X}})$ and standard deviation $(\mathrm{Sd})$.

\section{Results and Discussion}

Research results obtained in the analysis of the chemical composition of longissimus muscle in young cattle of different genotypes are presented in Table 1. Share of water, ash and proteins in meat showed no significant differences between cattle groups. Young cattle of genotype DxS had the highest share of intramuscular fat $(2.37 \%)$, which was statistically significantly different $(\mathrm{P}<0.05)$, whereas the young cattle in group D had the highest amount of total pigments (101.12 ppm) in muscle samples $(\mathrm{P}<0.05)$.

Table 1. Chemical composition of longissimus muscle in young cattle of different genotypes

\begin{tabular}{|c|c|c|c|c|}
\hline \multirow{2}{*}{ Chemical composition } & $\mathrm{D}$ & $\mathrm{D} \times \mathrm{L}$ & $\mathrm{D} \times \mathrm{S}$ & \multirow{2}{*}{$\begin{array}{l}\text { Effect of } \\
\text { genotype }\end{array}$} \\
\hline & $\bar{X} \pm \mathrm{Sd}$ & $\bar{X} \pm \mathrm{Sd}$ & $\bar{X} \pm \mathrm{Sd}$ & \\
\hline Water (\%) & $74.76 \pm 0.94$ & $74.56 \pm 0.77$ & $74.51 \pm 0.91$ & ns \\
\hline Fat $(\%)$ & $1.61^{\mathrm{a}} \pm 0.05$ & $1.82^{\mathrm{a}} \pm 0.07$ & $2.37^{\mathrm{b}} \pm 0.05$ & $*$ \\
\hline Ash (\%) & $1.03 \pm 0.03$ & $1.05 \pm 0.04$ & $1.02 \pm 0.02$ & ns \\
\hline Protein $(\%)$ & $22.60 \pm 0.97$ & $22.87 \pm 1.08$ & $22.10 \pm 0.90$ & ns \\
\hline Pigment content (ppm) & $101.12^{\mathrm{b}} \pm 3.67$ & $99.97^{\mathrm{ab}} \pm 4.27$ & $92.63^{\mathrm{a}} \pm 3.47$ & $*$ \\
\hline
\end{tabular}

In Table 2, the technological characteristics of muscle samples are presented. Initial $\mathrm{pH}$ value was in range from 6.93 to 6.95 , and final value from 5.66 to 5.69 and it was approximately the same in all groups of young cattle. Values of water binding capacity and cooking loss of meat, also, showed no significant differences between genotypes. Research carried out by Wulf et al. (1996) and Maher et al. (2004) show that breed had no effect on water binding capacity of beef meat, which is in concordance with results obtained in this study.

Slightly higher values of meat shear force (tenderness) were obtained in meat deriving from young cattle of group DxS $\left(7,10 \mathrm{~kg} / \mathrm{cm}^{2}\right)$. Nutrition, final weight, age and gender have very strong impact on meat quality. Research results reported by Sazili et al. (2003) and Purchas et al. (2002) indicate that different 
nutrition treatments had significantly influenced the meat tenderness. The same authors report that female animals have more tender meat compared to male animals.

Table 2. Technological characteristics of longissimus muscle in young cattle of different genotypes

\begin{tabular}{|c|c|c|c|c|}
\hline \multirow{2}{*}{ Technological properties } & $\mathrm{D}$ & $\mathrm{D} \times \mathrm{L}$ & $\mathrm{D} \times \mathrm{S}$ & \multirow{2}{*}{$\begin{array}{l}\text { Effect of } \\
\text { genotype }\end{array}$} \\
\hline & $\overline{\mathrm{X}} \pm \mathrm{Sd}$ & $\bar{X} \pm S d$ & $\overline{\mathrm{X}} \pm \mathrm{Sd}$ & \\
\hline pH (45 min p.m.) & $6.93 \pm 0.07$ & $6.94 \pm 0.04$ & $6.95 \pm 0.05$ & ns \\
\hline pH (24 hours p.m.) & $5.69 \pm 0.11$ & $5.66 \pm 0.07$ & $5.66 \pm 0.08$ & ns \\
\hline WBC $\left(\mathrm{cm}^{2}\right)$ & $11.21 \pm 0.58$ & $11.28 \pm 1.00$ & $11.45 \pm 1.17$ & ns \\
\hline Cooking loss (\%) & $39.07 \pm 2.31$ & $39.46 \pm 1.54$ & $38.84 \pm 1.73$ & ns \\
\hline Tenderness $\left(\mathrm{kg} / \mathrm{cm}^{2}\right)$ & $5.43^{\mathrm{a}} \pm 0.13$ & $5.99^{\mathrm{a}} \pm 0.13$ & $7.10^{\mathrm{b}} \pm 0.16$ & $*$ \\
\hline
\end{tabular}

In addition to the carcass and meat quality, sensory quality of meat is of great importance for consumer. Consumer habits in EU countries gravitate towards consumption of meat which subsequent to heat treatment shows excellent aroma/flavour, and at the same time is still tender and succulent (Aleksić et al., 1997). Ostojić et al (2008) and Troy (2011) state that meat tenderness is considered to be the most important sensory property of young beef and beef.

Crossing of domestic Simmental breed with noble cattle breeds influenced also the sensory acceptability of meat (Table 3 ).

Table 3. Genotype influence on sensory properties

\begin{tabular}{|c|c|c|c|c|}
\hline \multirow{2}{*}{ Attributes } & $\mathrm{D}$ & $\mathrm{D} \times \mathrm{L}$ & $\mathrm{D} \times \mathrm{S}$ & \multirow{2}{*}{$\begin{array}{l}\text { Effect of } \\
\text { genotype }\end{array}$} \\
\hline & $\bar{X} \pm S d$ & $\bar{X} \pm S d$ & $\overline{\mathrm{X}} \pm \mathrm{Sd}$ & \\
\hline Softness & $4.48 \pm 0.18$ & $4.75 \pm 0.20$ & $4.68 \pm 0.11$ & ns \\
\hline Succulence & $4.61 \pm 0.19$ & $4.53 \pm 0.27$ & $4.61 \pm 0.31$ & ns \\
\hline Taste/flavour & $4.45^{\mathrm{a}} \pm 0.11$ & $4.61^{\mathrm{ab}} \pm 0.15$ & $4.87^{b} \pm 0.14$ & $*$ \\
\hline Aroma & $4.70 \pm 0.14$ & $4.71 \pm 0.26$ & $4.70 \pm 0.27$ & ns \\
\hline
\end{tabular}

Sensory scores for tenderness (Table 3 ) should follow the values obtained for meat shear force (Table 2). However, no statistically significant difference was established between groups in regard to this parameter, because it depends on other factors such as pre-slaughter treatment and handling of animals and their carcasses post mortem, type of sampled muscle, preparation procedure for sensory analysis, etc., which can cause the variation. Statistically significant difference was established in evaluation of aroma/flavour of heat treated meat between young cattle of groups D (4.50) and DxS (4.87). 


\section{Conclusion}

Based on results obtained in the study of the effect of crossing domestic Simmental breed with French fattening breeds Limousine and Charolais on meat quality, it can be concluded that meat obtained from crosses is of high quality in regard to chemical and technological properties and has favourable sensory scores. Data obtained in this study justify the economic goal of crossing domestic Simmental breed with noble cattle breeds in production of meat of high quality, which is of interest both to producers (farmers) and final customer (consumer).

\section{Hemijske, tehnološke $i$ senzorne osobine mesa junadi različitih genotipova}

S. Aleksić, M. M. Petrović, V. Pantelić, Ž. Novaković, D. Ostojić-Andrić, N. Stanišić, D. Nikšić

\section{Rezime}

U radu je ispitivana mogućnost poboljšanja kvaliteta mesa domaće simentalske rase goveda (D) ukrštanjem sa francuskim tovnim rasama šarole (DxS) i limuzin (DxL). U ogled je bilo uključeno 25 meleza DxS rase junadi, 18 meleza rase DxL i 21 june rase D. Rezultati ispitivanja hemijskog sastava longissimus mišića junadi su se statistički značajno razlikovali $(\mathrm{P}<0.05)$ u procentu intramuskularne masti, koji je bio najveći kod junadi grupe DxS $(2.37 \%)$ i u količini ukupnih pigmenata, koja je bila najveća kod junadi grupe D (101.12 ppm). Junad grupe D su imala najmanju vrednost sile sečenja mesa nakon termičke obrade $\left(5.43 \mathrm{~kg} / \mathrm{cm}^{2}\right)$, tj. imala su najmekše meso. Dobijeni podaci za senzornu analizu kuvanog mesa su bili visoki i nisu se značajnije razlikovali između grupa. Statistički značajna razlika $(\mathrm{P}<0.05)$ je utvrđena samo u oceni ukusa, koja je bila nešto viša kod junadi grupe DxS (4.87). Podaci dobijeni u ovom ogledu opravdavaju ekonomski cilj ukrštanja domaće simentalske rase sa plemenitim rasama goveda u pravcu dobijanja mesa dobrog kvaliteta, što je od velikog interesa i za proizvođača (farmera) i za krajnjeg kupca (potrošača).

\section{References}

ALEKSIĆ S., LAZAREVIĆ R., MIŠČEVIĆ B., PETROVIĆ M. M., JOSIPOVIĆ S. (1997): Nove tehnologije za poboljšanje prinosa i kvaliteta junećeg mesa domaće šarene rase namenjenog izvozu. Biotehnologija u stočarstvu, posebna edicija, 17-26. 
ALEKSIĆ S., PETROVIĆ M.M., MIŠČEVIĆ B., PANTELIĆ V., TOMAŠEVIĆ D., OSTOJIĆ D. (2005): Production of high quality beef in accordance with European trends. Biotechnology in Animal Husbandry, 21, 5-6, 331-336.

ALEKSIĆ S., PETROVIĆ M.M., MIŠČEVIĆ B., SRETENOVIĆ LJ., PANTELIĆ V., TOMAŠEVIĆ D. (2006): Production of beef carcass according to consumers demands. $52^{\text {nd }}$ International Congress of Meat Science and Technology, 13-18. August 2006, Dublin, Ireland, Proceding, 541-543.

AOAC (1990): Official methods of analysis. Washington, DC: Association of Official Analytical Chemists.

BUCHTER L. (1985): Danish experiences in developing and operating specifications for beef. The long term definitions of meat quality: Controling the variability of quality in beef, veal, pig meat and lamb. Brussel, Luxemburg: Comm. Europ.Commun., 43-50.

BUNNING K., HAMM R. (1970): Über die haminbestimmung in fleisch mittels der methode von Horsney. Fleischwirtschaft, 50, 1541-1545.

ČOBIĆ T., NENADOVIĆ M., MEDIĆ D., NOVAKOVIĆ M. (1990): Ispitivanje tovnih sposobnosti muških meleza $F_{1}$ generacije šaroleske i limuzinske sa simentalskom rasom goveda. Biotehnologija u stočarstvu, 3-4, 3-13.

TROY D. (2011): Modern approaches to enhancing beef quality. Tehnologija mesa, Međunarodno 56. savetovanje industrije mesa, 52, 1, 15-21.

GRAU R., HAMM R. (1953): Über das wasserbindungsvermögen des toten säugetiermuskels. I. Mitteilung. Der Einfluß des pH Wertes auf die Wasserbindung von zerkleinertem Rindermuskel. Biochem. Z., 325, 1-11.

HARRINGTON G. (1985): Review of relative importance of factor up controlling the variability of quality in beef veal, pig, meat and lamb. Brussel, Luxemburg: Comm. Europ.Commun., 17-34.

MAHER S.C., MULLEN A.M., KEANE M.G., BUCKLEY D.G., KERRY J.P., MALONEY A.P. (2004): Decreasing variation in the eating quality of beef through homogenously pre and post-slaughter. Meat Science, 69, 215-224.

PURCHAS R.W., BURNHAM D.L., MORRIS S.T. (2002): Effect of growth potential and growth path on tenderness of beef longissimus muscle from bulls and steers. Journal of Animal Science, 80, 3211-3221.

OSTOJIĆ-ANDRIĆ D., BOGDANOVIĆ V., ALEKSIĆ S., PETROVIĆ M.M., MIŠČEVIĆ B., PANTELIĆ V., NOVAKOVIČ Ž. (2008): The effect of genotype on sensory and technological quality of beef. $7^{\text {th }}$ Symposium of Animal Biology and Nutrition, September 25-26, Balotesti, Archiva Zootechnica, 12, 1, 56-64.

SAZILI A.Q., LEE G.K., PARR T., SENSKY P.L., BARDLEY R.G., BUTTERY P.J. (2003): The effect of growth rates on the calpain proteolytic system and meat tenderness in cattle. Meat Science, 66, 195-201.

WULF D.M., MORGAN J.B., TATUM J.D., SMITH G.C. (1996): Effects of animal age, marbling score, calpastatin activity, subprimal cut, calcium injection, and degree of doneness on the palatability of steaks from limousin steers. Journal of Animal Science, 74, 569-576. 